\title{
Influence of Citrus Species To Biology And Development of Citrus Silver Mite Polyphagotarsonemus latus (Banks) (Acari:Tarsonemidae)
}

\author{
Susi Wuryantini ${ }^{1)}$, Retno Dyah Puspitarini ${ }^{2)}$ and Aminudin Affandhi ${ }^{3)}$

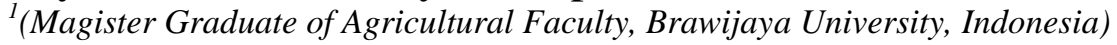 \\ (Indonesian Research Institute for Citrus and Subtropical Fruits) \\ 2,3 (Lecturer of Agricultural Faculty, Brawijaya University, Indonesia)
}

\begin{abstract}
Citrus Silver Mites (CSM) Polyphagotarsonemus latus (Banks) in Indonesia has been known as a major pest of tea plant, sesame and jatropha. Recently CSM was found attacking citrus plant. Plant damage caused by mites on the leaf buds are curved, curly shoots and dead ends. This condition was found in the screen house of some nurseries for several citrus varieties. Because of the damage, the control anticipation based on bioecology must be taken seriously. The study was conducted on the biology and development of CSM on three commercial citrus species that were Tangerine, Sweet Orange and Mandarin. The results showed that in general, CSM life cycle on three citrus species was not significantly different, which was about 5 days. Pre oviposition period, oviposition period, longevity of adult female, post oviposition period did not differ between the three citrus species. The fecundity of CSM on Sweet Orange was higher than that of Tangerin and Mandarin which were respectively $41.22 ; 26.22$ and 29.32 eggs per female. Sex ratio was 1:4,75 on Tangerin, Sweet Oranges and the Mandarin were respectively 1:405 and 1:4.68.
\end{abstract}

Keywords : Biology, citrus species, development, Polyphagotarsonemus latus

\section{INTRODUCTION}

Citrus silver mites (CSM) Polyphagotarsonemus latus (Banks) (Tarsonemidae) was one of the important pests that attack citrus. CSM was found on citrus in California in the fall of 1979 on lemon [1]. In Turkey mites were found on young plants in the nursery at the screen house in 1992 [2]. CSM spreads almost all over the world. These mites have many common name; in India and Sri Lanka it is called yellow tea mite; in Bangladesh it is called jute yellow mite; in some European countries it is called broad spider; in the Southern of America it is called tropical broad mite or rust mite. This mite is also popularly known as the broad mite, citrus silver mite, chilli mite, jute white mite, rubber leaf mite [3], [4].

In Indonesia CSM attacks several plants including tomatoes, peppers, rubber plant, tea, sesame and jatropha. Damage caused by CSM attacks generally showed as deformation of leaves and flower buds. The toxic saliva's mite caused swollen, hardened and distorted growth [5], [6], [7]. Affected leaves grow abnormally, like rolling, narrow and chlorotic, curling down and the color become like copper or purplish. Plant segment become shorten, lateral buds grow abnormally, flowers drop and plant growth become stunted [4], [7]. The mites attack on tea plant resulted in disturbed elongation of shoot, chlorosis, leaf shrinking and curling. Brown line visible on the side of the main veins on older leaves indicate the mites have been able to reach the ends of the leaves which are curling when it's young [8].

Tarsonemid mite has been found in mandarin plantation in Indonesia, but the species has not been identified [9]. Survei in 2012 showed that there were CSM attack on the screen house in the citrus nursery at Research Institute for Citrus and Subtropical Fruit. Some of citrus species including rootstocks Japanese Citroen (JC), Tangerines and Mandarins on the screen houses showed symptomps like shoots curling downward and upward, rough leaves and shrinked, wrinkled, curly, leave color changed, and dry shoot tips which then fall off. Bud damage may result in declining of citrus seed quality. Low quality seed will result in sub-optimal plant growth that will affect the growth and production.

With the discovery of CSM attack on citrus, especially in commercial citrus, anticipatory management actions are necessary to prevent losses. The basic information required in the management of CSM is about biology, the host and environment. Different host and different agroclimate conditions might affect the biology of CSM. Important aspects of biology to be studied including morphology, pre adult development, life cycle, sex ratio, type of reproduction, adult longevity and fecundity. The study aimed to determine the effect of citrus species, Tangerines, Sweet Orange and Mandarins on biology and development of CSM. 


\section{Material And Method}

The study was conducted at the Entomology Laboratory and screen house of Indonesian Research Institute for Citrus and Subtropical Fruits (IRICSF), Tlekung, Batu, Indonesia. The research was conducted in the laboratory with a mean temperature of $25^{\circ} \mathrm{C}$ and humidity of $80 \%$ in December 2012 to May 2013.

Mites as research objects were collected from infested nursery screen house then reared on three citrus species tested. Rearing was done in the screen house on 1-2 years old of citrus plants at shooty conditions. The number of plant observed was at least 30 plants for each citrus species. Plants divided into 5 groups were pruned to provide the shoots that will be used as host.

Experimental site was leaves that were put in a Petri dish that has a wet sponge or submerged in water. The top of the sponge was covered with tissue paper as the base of the leaf to be used for the experiment. The young leaves used were 10-15 days old and were placed on experimental site. On the edge of the leaf tissue paper was put around to prevent the mites going out from the experimental site.

Parameter observed in this research were morphology, preadult development, life cycle, sex ratio, reproduction type, adult longevity and fecundity. To determine the morphology and development of pre mature CSM, observations were made on shape and size of eggs, shape and size of each stadium development and the duration of them. Measurements were performed on 20 replications. Observation was done using binocular microscope with a 100 times magnification. The pre adult development was observed every 3 hours. To determine the life cycle of CSM, observation mentioned above was conducted until the adult female laid its first egg.

Sex ratio was determine by placing some female of CSM in experimental site for 24 hours in order to laid eggs. The eggs laid were observed until adulthood. Observations were made every day to record the CSM that still alive. Sex ratio was determined from the emerging adult. Observations were made on 100 eggs, for each citrus species. To determine the reproduction type of CSM, two treatments were made, mating and not mating females. For not mating treatment, one adult female were placed on experimental site. Eggs laid were allowed to grow up to adult. Note was taken on sex of emerging adult. Experiments were carried out on 20 female as replications. The same procedure was applied for the treatment of mating, the females were placed with the males.

Observations to know the longevity of adult and fecundity were made by placing a newly emerging female and one male of CSM. Treatment was repeated 40 times from mite populations reared together and emerged on the same day. Each experiment was placed in the experimental site. The number of eggs laid each day was recorded, then the eggs removed. Observations were done every day until the female dies. The same treatment is applied to determine the male longevity.

Effect of citrus species against biology of CSM were determined by Analysis of Variance (ANOVA). Diferences between the parameters compared with Duncan's Multiple Range Test $(P \leq 0.05)$ using the Statistical Analysis System (SAS) program. This linear regression model was used to determine the relationship between proximate contained in these three citrus species and the biological parameters.

\section{Result}

CSM consists of 4 stadium that were egg, larvae, nymph and adult (Figure 1). The eggs were round or slightly oval with a length of $107 \pm 5 \mu \mathrm{m}$ and a width of $77 \pm 6 \mu \mathrm{m}$ (Table 1). Eggs surface that adhere on the leaves were flat, and convex on the outer surface and there were white bumps with line shape along the surface of the egg. The number of bumps were 42-62 arranged on 7-8 rows. Newly laid eggs were very transparent. Towards hatching, the eggs become turbid but still translucent and rows of white bumps became irregular, then cracked and hatched.

Larvae emerging from egg was white turbid, somewhat transparent with a length of $137 \pm 20 \mu \mathrm{m}$ and a width of $81 \pm 9 \mu \mathrm{m}$. Larvae of CSM has three pairs of legs which was colorless and moving slowly. Nymph body length of CSM was $218 \pm 13 \mu \mathrm{m}$ and a width of $98 \pm 6 \mu \mathrm{m}$ and had shape similar to elongating larvae and tapered on its ends. The nymphs' body was very transparent or translucent and the legs were closer to the body. Fore legs leads to the front or anterior portion, as well as the two hind legs pointing towards the posterior.

Adult of CSM has four pairs of legs. Newly emerged females and not laid eggs yet was round, transparent but rather murky. At the posterior part there is almost triangular-shaped white mark. Adult male body size is smaller, slimmer body shape and elongated compared to that of females. Male legs are longer and more spread than females. Males move faster than females. The size of adult male was $159 \pm 25 \mu \mathrm{m}$ lengt and $85 \pm 2 \mu \mathrm{m}$ wide. 

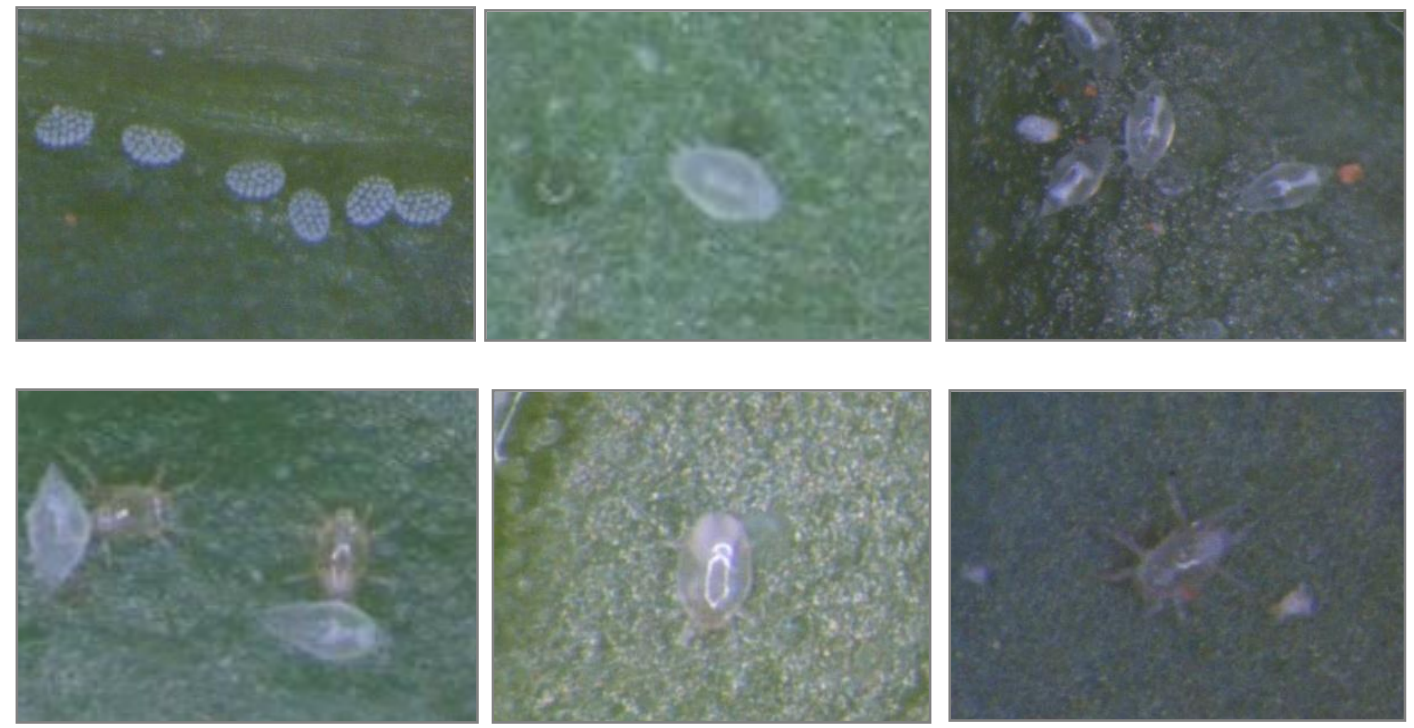

Figure 1. Life stadium of CSM; a: egg, b: larvae, c: nymphs d: adult males carrying female nymph, e: adult female, f: adult male

Development time of eggs and larvae were not significantly different on the three citrus species. In this study, differences was found in the duration of nymph stadium; it was longer on sweet orange and significantly different with tangerines but not significant with mandarins (Table 2).

In the larval stage, after eating activity during a certain period, the larva will enter quiescent stage and turned into a nymphs with the body resides in the skin. The life cycle of CSM on the three citrus species were not significantly different, which was about 5 days (Table 2). In citrus, sex ratio of CSM was quite high, that was 1:4,75 on tangerines, 1:4,05 on the sweet orange, and 1:4,68 on mandarin citrus (Table 3 ).

Table 1. Size of each stadium of CSM

\begin{tabular}{ccc}
\hline Stadium & Length $(\mu \mathrm{m})$ & Width $(\mu \mathrm{m})$ \\
\hline Egg & $107 \pm 5$ & $77 \pm 6$ \\
Larvae & $137 \pm 20$ & $81 \pm 9$ \\
Nymph & $218 \pm 13$ & $98 \pm 6$ \\
Adult female & $170 \pm 20$ & $100 \pm 9$ \\
Adult male & $159 \pm 25$ & $85 \pm 2$ \\
\hline
\end{tabular}

Tabel 2. Pre adult parameters and life cycle of CSM on three citrus species

\begin{tabular}{lccc}
\hline Stadium period & Tangerin & Sweet orange & Mandarin \\
\hline Egg (hours) & $47,45 \mathrm{a}$ & $46,95 \mathrm{a}$ & $47,85 \mathrm{a}$ \\
Larvae (hours) & $23,35 \mathrm{a}$ & $23,10 \mathrm{a}$ & $22,20 \mathrm{a}$ \\
Nyph (hours) & $19,35 \mathrm{~b}$ & $22,60 \mathrm{a}$ & $21,30 \mathrm{ab}$ \\
Life cycle (days) & $5,01 \mathrm{a}$ & $5,16 \mathrm{a}$ & $5,04 \mathrm{a}$
\end{tabular}

Note: Number followed by the same leter in each row was not significantly different at 5\% DMRT

Duration of pre adult development of CSM on three citrus species in general was not significantly different. Longevity of not mating adult females on Sweet Orange was significantly different from Tangerines and Mandarins. Adult longevity of mating CSM was shorter than not mating (Table 3 ).

CSM that were mating produced male and female offspring, but those were not mating produced only males. Fecundity of CSM on Sweet Orange was significantly higher than Tangerines and Mandarins, that were 41.22; 26.22 and 29.32 eggs per female respectively. The oviposition period in sweet oranges was also higher than tangerines and mandarins, which then determining the number of eggs laid. 
Tabel 3. Life adult parameter of CSM on three citrus species

\begin{tabular}{lccc}
\hline \multicolumn{1}{c}{ Parameter } & \multicolumn{2}{c}{ Citrus species } \\
\cline { 2 - 4 } & Tangerin & Sweet orange & Mandarin \\
\hline Pre oviposition period (hours) & $30,0 \mathrm{a}$ & $31,3 \mathrm{a}$ & $29,7 \mathrm{a}$ \\
oviposition period (hours) & $9,50 \mathrm{a}$ & $10,55 \mathrm{a}$ & $9,40 \mathrm{a}$ \\
Longevity of adult female (days) & $12,22 \mathrm{a}$ & $12,78 \mathrm{a}$ & $13,25 \mathrm{a}$ \\
Longevity of adult male (days) & $9,32 \mathrm{a}$ & $8,05 \mathrm{~b}$ & $8,10 \mathrm{~b}$ \\
Fecundity (per female) & $26,22 \mathrm{~b}$ & $41,22 \mathrm{a}$ & $29,32 \mathrm{~b}$ \\
Post oviposition period (hours) & $1,78 \mathrm{a}$ & $1,50 \mathrm{a}$ & $1,88 \mathrm{a}$ \\
Sex ratio & $1: 4,75$ & $1: 4,05$ & $1: 4,68$ \\
Longevity of adult female without mating (days) & $16,60 \mathrm{a}$ & $14,20 \mathrm{~b}$ & $16,25 \mathrm{a}$ \\
Longevity of adult male without mating (days) & $9,65 \mathrm{a}$ & $8,95 \mathrm{a}$ & $7,15 \mathrm{~b}$ \\
\hline
\end{tabular}

Note: Number followed by the same leter in each column was not significantly different at 5\% DMRT

Regression analysis on the influence of the content of proximate against the CSM's life was conducted on the fecundity and sex ratio parameters which can be used to indicate the population growth of CSM. Proximate analysis on three citrus species tested showed that the protein levels found in Sweet Orange shoots was higher than Tangerines and Mandarins (Table 4). Levels of protein and ash content correlated positively with very strong criteria with fecundity $(\mathrm{y}=0.127 \mathrm{x}=2.149 ; \mathrm{r} 2=0.977)$, as well as ash content $(\mathrm{y}=0.045 \mathrm{x}-$ $0.282 ; \mathrm{r} 2=0.999)$. Water content, fat content, carbohydrate and crude fiber were negatively correlated with CSM fecundity.

Table 4. Proximat content on three citrus species shoots

\begin{tabular}{lcccccc}
\hline \multicolumn{1}{c}{ Citrus species } & $\begin{array}{c}\text { Water } \\
\text { content }(\%)\end{array}$ & $\begin{array}{c}\text { Protein } \\
(\%)\end{array}$ & $\begin{array}{c}\text { Fat } \\
(\%)\end{array}$ & $\begin{array}{c}\text { carbohydrate } \\
(\%)\end{array}$ & $\begin{array}{c}\text { Ash content } \\
(\%)\end{array}$ & $\begin{array}{c}\text { Crude fibre } \\
(\%)\end{array}$ \\
\hline Tangerin & 77,82 & 5,29 & 0,13 & 15,84 & 0,92 & 2,06 \\
Sweet orange & 76,71 & 7,34 & 0,07 & 14,29 & 1,59 & 1,88 \\
Mandarin & 77,24 & 6,12 & 0,06 & 15,15 & 1,03 & 2,25 \\
\hline
\end{tabular}

Proximate content on citrus leaves also affects the sex ratio of CSM. Water content, carbohydrates, and crude fiber showed positive correlation with very strong criteria to CSM sex ratio with $\mathrm{r}^{2}$ of $0.889 ; 0.927$ and 0.817 respectively. Fat levels were intermediate correlated with a correlation coefficient of 0.449 , while protein and ash content has a negative correlation with CSM sex ratio.

\section{Discussion}

On citrus leaves, eggs were often found along the veins. About two days, the eggs hatched into larvae. In general eggs of CSM were laid individually and a small portion was laid in groups on the basin of leaves. According to [10] the egg size is relatively large compared with the adult female, laid on a flat leaf surface and will hatch in 2-3 days. [11] also state that the CSM eggs were usually laid individually on the bottom surface of young leaves or emerging shoots. In fruit, eggs laid in the sheltered hollows or on the rind. According to [12], [13], [5] on previous studies, CSM egg was colorless and elliptical with a size of $0.08 \mu \mathrm{m}$. The number of the egg white bumps found on citrus in this research was 42-62, higher than that of their studies before, around 2937.

The size of three pairs of legs on larvae become bigger as they aged. Towards the nymph stadium, the body shape of larvae was elongated and the color became more transparent. [4] stated that the larvae will emerge from two to three days old eggs. Larvae were out from eggs shell to eat. The larvae move slowly and do not move far. Larval stage lasts for 2-3 days and then become idled nymphs [2].

Nymph body resides in the colorless or transpaent skin of larvae. In the body there were white markings nymphs resemble the $\mathrm{T}$ shape in the posterior and looked very clear. [4] mentions that the body nymph is transparent and tapered at both ends. Adult body with 8 legs was formed in the nymphs skin [10]. [2], [14] and [11] also mention that the nymph looks like an enlarged larvae. Nymphs were formed in the skin of larvae until becoming adult, motionless and starving. In the nymph that was almost no shape difference between male and female, except on the fourth leg. Fourth leg of male was enlarged, while the female is reduced and shaped like a whip.

Towards becoming adult, female nymphs carried by the adult male and lifted using hind legs. This 'holding' position of which the female nymphs placed on the dorsal side of the male body and the central edge of that female nymphs were supported. At this time the male attempted to bring the female nymphs as he moved 
while waiting for the nymphs becomes adult. Copulation was immediately occurs when the nymph becomes adult.

Female nymph attract the male to pick and bring it to a new leaf. Males have a habit of carrying a female nymphs, placed on the genital papilla. In this activity, the fourth leg pair serves as lifter to put the female on the site. The process was done by lifting it high above the posterior part of the male body, held strong by the genital organs similar to sucker. Males who do not get females often try to rob the female brought by the other males, but usually was not succesfull [15], [10]. Holding behavior as described above occurs for approximately 24 hours, and is referred to as 'precopulation' or 'precopulatory guarding' [16] , [7].

Life cycle of CSM on citrus that lasts for 5 days was shorter than than that of CSM reared on pepper and cucumber plants as mentioned by [17], which lasts between 6-9 days. [10] stated that the life cycle of a newly laid egg to adult lasted for 4-5 days in warm weather, and longer up to 7-10 days in cold weather. Sex ratio CSM on citrus was higher than found by [17] on pepper and cucumber plants with sex ratio respectively were $27: 76$ or $1: 3.17$.

CSM emerged from the nymphs skin and exit by tearing the dorsal part. Emerging females that not yet laying eggs were transparent but somewhat murky, on the posterior part there was almost triangular-shaped white mark. the body of already laying eggs female become yellowish and more translucent or transparent, and the color becomes more yellow or greenish yellow as they ageing. [12] stated that the new adult females tend to be round shaped. In the female body there was a white mark on its dorsal. Adult females were larger in size, oval and yellowish. [10] also stated that new emerging females are transparent and will be yellow or greenish yellow.

Adult males are smaller in body size, and slender. Legs of males are longer and spread more than females, allowing mites move faster. According to [2] adult males was $120 \pm 16 \mu \mathrm{m}$ in length and $60 \pm 1.5 \mu \mathrm{m}$ in width. At the apex on the ventral side, the organ that resembles the suckers used to hold and carry female nymphs. The body color of adult males was yellowish white and transparent. This is consistent with previous studied by [12] and [10] that the body of the adult male was oval and shorter than that of the adult female. Male body color was more yellowish or brownish yellow, while females was transparent. According [4] and [13], the male and female of CSM were very active, but the male are more active in the role of spreading the population, especially to bring the female nymphs to new young leaves. The color of CSM was affected by the color of the part of the plant that used for food or the host of the mites.

The results showed that the CSM was pertenogenesis breeding. The mating CSM produced male and female progeny, and the not mating CMS produced males only; therefore the type of mite reproduction is categorized as arhenotokus. The mite reproduction was sexual, but occurs by parthenogenesis arhenotokus [14]. [10] also stated that if the fertilization delayed, females can still produce eggs, but only produce male. females were relatively sedentary compared to males. Females laid 2-4 eggs per day during their lifetime, which lasts about 10 days. Observations also indicated that the longevity of adult females was longer than that of males.

Longevity of mating adult was shorter than not mating one. The difference was due to the mating mites require more energy than non mating ones, therefore it runs out faster results in shorter life. In the process of mating insects require extra nutrition [18]. Nutrition required by the female imago is often added by the provision of male. In this process the main nutrients needed are proteins, which affect the size and number of eggs produced.

From regression analysis, it can be explained that the number of eggs laid directly proportional to protein and ash content in citrus leaves. In contrast, the number of eggs varies inversely with levels of the water content, fat, carbohydrate and crude fiber. Water content, carbohydrate, crude fiber and fat content was proportional to the sex ratio of CSM, while protein and ash content was inversely proportional to the sex ratio of CSM. The oviposition period and number of eggs of CSM on Sweet Oranges were higher and significantly different than Tangerines and Mandarins. Oviposition period were related to the number of eggs laid.

The composition of the nutrients contained in the host, in this case on the citrus leaf affected CSM life parameters on citrus. [19] stated that the protein is a major component in the growth and development of mites, especially for egg formation. The difference in quality and chemical balance of nutrients or feed insects can produce significant changes [18]. On citrus red mite Panonychus citri (Mc. Gregor), the different citrus species influences on biology. Protein levels in lemon higher than that of sweet oranges; these conditions affect the development of the various stadium in lemon which is shorter, but fecundity and longevity of imago were higher than those of sweet orange [20]. However, CSM life parameters were not only influenced by nutritional factors, but there were also influenced by other factors such as biotic and abiotic environment.

\section{Conclusions}

Pre adult development and life cycle of CSM was nof affected by three citrus species. The fecundity of CSM on sweet oranges was higher and significantly different than that of tangerines and mandarins. The results 
of this research can be used as management guide of the CSM. Study on various aspects of CSM is needed to support the technology of Integrated Pest Management on citrus.

\section{Refference}

[1] Brown, R.D. dan V.P. Jones. The broad mite on lemons in Southern California. California Agriculture, 37 (7-8), 1983, $21-22$.

[2] Uygun, N., R. M.Ulusoy., I.Karaca. A citrus pest in East Mediteranean region of Turkey, Polyphagotarsonemus latus (Banks) (Acarina, Tarsonemidae). Turk. Entomol. Derg. 19(1), 1995, 1 - 4.

[3] Anonymous. Polyphagotarsonemus latus. Download http://www.caripestnetwork.org/vtt/docs/datasheets/acarina/polyphagotarsonemus_latus.pdf. at October 10th, 2012.

[4] Fasulo, T.R. 2010. Broad Mite, Polyphagotarsonemus latus (Banks) (Arachnida: Acari: Tarsonemidae). Entomology and Nematology Department, Cooperative Extension Service, Institute of Food and Agricultural Sciences, University of Florida. Download from http://edis.ifas.ufl.edu at September 14th 2012.

[5] Baker J.R. 1997. Cyclamen mite and broad mite. Ornamental and Turf Insect Information Notes. Download from http://www.ces.ncsu.edu/depts/ent/notes/O\&T/ flowers/note28/note28. html at September 14th 2012.

[6] Tukimin SW. Beberapa Aspek Biologi Tungau Kuning Polyphagotarsonemus latus (Banks) pada Beberapa Aksesi Wijen (Sesamum indicum L.). Agritek. 15(2), 2007.448-452.

[7] Puspitarini RD. Tungau Fitofag Pertanian dan Perkebunan di Indonesia. (Penerbit Selaras, 2011).

[8] Kalshoven L.G.E. Pest of Crops in Indonesia. (Revised by P.T. Ichtiar Baru-van Hoeve, Jakarta. 1981).

[9] Affandi. Abundance of Predatory Mites Family Phytoseiidae in The Ecosystem of Mandarin Citrus. Agrivita 31 (2), $2009,105-117$.

[10] Gerson U. Biology And Control Of The Broad Mite. Polyphagotarsonemus latus (Banks) (Acari:Tarsonemidae). Experimental \& Applied Acarology, 13(3), 1992, 163-178.

[11] Jayma LMK, Ronald FLM. Broad Mite. Polyphagotarsonemus latus (Banks). Crop Knowledge Master. Departement of Entomology. Honolulu, Hawaii, 2007.

[12] Denmark, H.A. Broad mite, Polyphagotarsonemus latus (Banks). FDACS-DPI Bureau of Entomology Circular No. 213. 2 p. 1980.

[13] Peña JE, C.W Campbell. Broad mite. Download from DIS. http://edis.ifas.ufl.edu/CH020, 2005.at 14 September 2012.

[14] Jeppson L.R., H.H. Keifer dan E. W. Baker. Mites Injurious To Economic Plants. (Berkeley, University of California, 1975).

[15] Vieira M.R. dan L.G. Chiavegato. Biologia de Polyphagotarsonemus latus (Banks, 1904) (Acari: Tarsonemidae) Em Algodoeiro. Pesq. Agropec. Bras. 33 (9), 1998, 1437-1442.

[16] Zhang ZQ. Mites of Greenhouses. (Cabi Publishing. USA, 2003).

[17] Montasser, A.A, A.M. Taha, A.R.I. Hanafy, dan G.M. Hassan. Biology and Control of the broad mite Polyphagotarsonemus latus (Banks, 1904) (Acari:Tarsonemidae). International Journal of Environtmental Science and Enginering (IJESE) 1: 2011.26-34.

[18] Chapman RF.. The Insects. Stucture and Function. 4th edition. (Cambridge University Press, 1998)

[19] Crooker A. Embryonic And Juvenile Development. in Helle W, Sabelis MW (ed.). Spider Mites Their Biology, Natural Enemies, And Control. Vol 1A. Amsterdam, Oxford, New York, Tokyo: Elsevier. 1985.149-163.

[20] Puspitarini, R.D. Biologi dan Ekologi Tungau Merah Jeruk, Panonychus citri (McGregor) (Acari:Tetranychidae). Disertation. Sekolah Pasca Sarjana. Istitut Pertanian Bogor, 2005. 